\title{
1. Arms control law approach to countering nuclear terrorism
}

On 22 March 2016, suicide bombers killed 32 people in Brussels, Belgium, in attacks at the international airport and Maelbeek metro station. Responsibility for these atrocious attacks was claimed by the extremist group known as, among other names, the Islamic State of Iraq and the Levant (ISIL). Immediately following the attacks, as part of the measures taken, non-essential workers were sent home from two nuclear power plants, Doel and Tihange. ${ }^{1}$ The evacuation may have seemed unusual as the 22 March attacks did not involve nuclear material or facilities, and the respective nuclear power plants are quite a distance from Brussels where the attacks took place. However, there was reason for the abundance of caution. In November of 2015, authorities had found surveillance footage of a senior official from Tihange nuclear power plant at the residence of a man suspected to have been involved in the terrorist attacks that November in Paris, and the perpetrators of the Brussels attack may have been connected. ${ }^{2}$

A couple of years prior to the attack in Brussels, a man who had worked for a contractor and had access to sensitive areas of the Doel nuclear power plant was convicted in absentia for jihadist recruitment and died in 2014 while fighting in Syria.

In the summer of 2014, ISIL took control of Mosul, the second largest city in Iraq, with reports that the militants had seized nearly 40 kilograms of nuclear material, namely natural uranium, from a research facility at the city's university. Fortunately, the "low-grade" 3 form of the material meant that it posed no real threat of being used in a weapon. Perhaps more concerning, though, is that radiotherapy machines containing radioactive cobalt- 60 were also stored on the university's campus. The cobalt-60 in combination with conventional

1 S. Mufson, 'Brussels attacks stoke fears about security of Belgian nuclear facilities,' The Washington Post, 25 March 2016; K. Vick, 'ISIS Attackers May Have Targeted Nuclear Power Station,' Time, 25 March 2016.

2 A. Chrisafis, 'Belgium steps up security at nuclear sites in wake of attacks,' The Guardian, 25 March 2016.

3 See A. Cowell, "Low-Grade” Nuclear Material Is Seized by Rebels in Iraq, U.N. Says,' The New York Times, 10 July 2014 (citing a statement by Gill Tudor, spokeswoman for the International Atomic Energy Agency). 
explosives could have been used in a so-called dirty bomb, spreading radiation and thereby potentially causing burns, radiation sickness and even death. For reasons unknown, the terrorists never used, or maybe by luck never even found, these radioactive sources. ${ }^{4}$

Anders Breivik, an extreme right-wing terrorist who was convicted of killing 77 people in Norway in 2011, wrote in a 1,500-page manifesto about attempting to acquire chemical, biological, radiological or nuclear materials. He also wrote about building and detonating a "radiological bomb" with stolen or purchased radioactive materials. ${ }^{5}$

The list goes on. In most cases, it is difficult to say why a nuclear, or radiological, terrorist attack did not end up happening. What is less hard to fathom is why a nuclear or radiological weapon would be sought by terrorists or terrorist groups bent on causing the most death, destruction and panic they can. There is no more destructive weapon than a nuclear weapon, and the non-nuclear malicious release of radioactivity would likely cause immense panic. This is why, in particular following the terrorist attacks in the United States on 11 September 2001 ("9/11"), the dangers posed by the possibility of terrorists or terrorist groups obtaining and using weapons of mass destruction has come to be seen as one of the most pressing threats to international peace and security. The attacks on 11 September 2001 did not involve nuclear or other radioactive material nor were they directed at nuclear facilities. However, the intent of the perpetrators to cause casualties and damage indiscriminately on such a massive scale raised the specter that such actors would seek to employ the most destructive weapon known to man to achieve their aims. This, coupled with the knowledge that a number of terrorist organizations - Al Qaeda, Chechen separatists, Lashkar-e-Taiba and Aum Shinrikyo among them ${ }^{6}$ - have

4 See J. Warrick and L. Morris, 'How ISIS nearly stumbled on the ingredients for a "dirty bomb",' The Washington Post, 22 July 2017.

5 See M. Bunn, 'The danger of radiological terrorism - and steps to reduce the risk,' presentation delivered to the FBI Boston Office, 26 September 2018, available at https://scholar.harvard.edu/files/matthew_bunn/files/the_danger_of_radiological terrorism_and_steps_to_reduce_the_risk.pdf (last accessed on 20 January 2019). See also 'Norway Killer Claims Allies Are Attempting to Acquire WMD,' Nuclear Threat Initiative, 28 July 2011, available at https://www.nti.org/gsn/article/norway-killer -claims-allies-are-attempting-to-acquire-wmd/ (last accessed on 15 March 2015).

6 See, for example, P. Malone and R.J. Smith, 'The Islamic State's Plot to Build a Radioactive "Dirty Bomb",' Foreign Policy, 29 February 2016; I. Ersan, 'Al Qaeda say would use Pakistani nuclear weapons,' Reuters, 22 June 2009; R. Kanani, 'New al-Qaeda Chief Zawahiri has Strong Nuclear Intent,' Forbes, 29 June 2011; R. Mowatt-Larssen, 'Al Qaeda Weapons of Mass Destruction Threat: Hype of Reality,' Belfer Center for Science and International Affairs, January 2010 (including timeline of terrorists' efforts to acquire WMD). 
demonstrated interest in obtaining nuclear weapons, and the well-documented vulnerabilities of nuclear/radioactive material and facilities, ${ }^{7}$ led to increased international activity to address this threat.

International efforts to control nuclear energy - the related materials, applications, facilities and technologies - have evolved greatly since the first and only use of nuclear weapons against Japan in 1945, towards the end of World War II. The devastation wrought by relatively small bombs, in terms of the nuclear material employed, ${ }^{8}$ shocked the conscience of the international community and led to immediate attempts to prevent nuclear weapons from ever being used again. A basic principle underlying such efforts was that nuclear energy should only be used for peaceful purposes, considering applications for energy production and medicine, among others, with the paramount consideration being the protection of people, the environment and society. The era of modern arms control was ushered in to reduce the dangers of nuclear weapons - including through addressing the spread, or proliferation, of nuclear weapons; prohibiting (certain forms of) nuclear weapons testing; and eventually reducing numbers or eliminating categories of nuclear weapons, primarily through bilateral agreements between the United States and the Soviet Union/ Russian Federation. While the intervening years have seen the number of states with nuclear weapons increase to nine, not to mention a number of others that have embarked upon and then reconsidered nuclear weapons programs or those states that remain causes for concern while not yet having taken the step of producing a nuclear weapon, nuclear arsenals are significantly smaller than they were at the height of the Cold War. Fewer states possess nuclear weapons than was originally feared would be the case. ${ }^{9}$ Nonetheless, nuclear weapons still feature heavily in security strategies and military doctrines.

7 A famous example of the vulnerability of nuclear material in weapons programs, which is supposed to be material that is secured to the highest standards, was the break-in by an 84-year-old nun at the Y-12 National Security Complex in the United States. The complex is the primary storage facility for highly enriched uranium for nuclear weapons for the United States. See E. Schlosser, 'Break-In at Y-12: How a handful of pacifists and nuns exposed the vulnerability of America's nuclear-weapons sites,' The New Yorker, 9 March 2015.

${ }^{8}$ According to the World Nuclear Association, around 60 kilograms of highly enriched uranium was used in the bomb that was dropped on Hiroshima, and the explosive charge of the bomb dropped on Nagasaki three days later came from eight kilograms of plutonium, available at www.world-nuclear.org. The explosive yields were about 15 kilotons and 21 kilotons, respectively.

9 US President John F. Kennedy famously predicted that " 10,15 , or 20 nations" would have nuclear weapons capabilities in his Presidential debate with Richard Nixon on 13 October 1960. 
On the non-weapons side, three major accidents involving nuclear power plants - Three Mile Island in the United States (1979), Chernobyl in the Soviet Union (1986) and Fukushima Daiichi in Japan (2011) - have prompted a range of reactions at various times, including the strengthening of the international nuclear safety framework in the wake of Chernobyl and following the Fukushima accident.

Notwithstanding these efforts and related issues, the capability to develop and make use of atomic energy, nuclear science and technology has continued to spread apace, and the number of peaceful uses for nuclear and other radioactive materials has increased. Unfortunately, it was inevitable that nefarious non-state actors would eventually seek to misuse these same materials and facilities to cause harm. In recognition of and to combat this threat, the concept of nuclear security was devised, which is the main focus of this book.

Generally speaking, nuclear security can be defined as the "prevention of, detection of, and response to, criminal or intentional unauthorized acts involving or directed at nuclear material, other radioactive material, associated facilities, or associated activities." 10 Immediately clear from the definition is that nuclear security is not solely, perhaps even not primarily, an issue of international law. The focus on specific acts - "criminal or intentional unauthorized acts" - concerns domestic law, particularly when it comes to contravention of authorizations. This explains why, from the beginning, nuclear security has been formulated as fundamentally a national responsibility of states. This is due primarily to the fact that nuclear security touches upon domestic law enforcement, national defense and intelligence activities and energy production, among other sensitive sectors, meaning that it can be seen to pertain to fundamental aspects of national sovereignty. However, the scope and scale of previous nuclear incidents with transboundary effects, the international operations of terrorist networks, and the demonstrable threat of nuclear terrorism show that risks and threats to nuclear security cannot be confined to within national borders. Rather, there is a common interest in preventing and combatting the threat of nuclear terrorism as a matter of national, regional and international security. Some aspects of nuclear security do lend themselves clearly to an international legal solution. For example, harmonizing requirements for physically protecting nuclear material and facilities, thereby preventing malicious non-state actors from acquiring or gaining access to materials and facilities, is crucial to preventing acts of nuclear terrorism. Important is that this be an international undertaking, to avoid weaknesses in nuclear security frameworks that could be exploited, which means the requirements can best be

10 International Atomic Energy Agency, Objective and Essential Elements of a State's Nuclear Security Regime, Nuclear Security Series No. 20, p. 1. 
codified in an international legal instrument. Similarly, response activities in the event of a nuclear terrorist attack can be carried out at the national level, but because of cross-border effects of such incidents, particularly due to the possible spread of radiation, response can also involve assistance with, inter alia, recovery and subsequent protection of stolen material. The response and mitigation framework can logically be laid down in international legal instruments.

Another point that should be made here is that the definition of nuclear security above foresees action by states to address acts of non-state actors. There is a distinction that can be made, then, when it comes to thinking about nuclear security in relation to the more "traditional" forms of arms control, such as non-proliferation of nuclear weapons. The latter, in the common arms control parlance, primarily concerns preventing states from diverting nuclear energy from peaceful uses to nuclear weapons or preventing states from obtaining nuclear weapons (for military use), whereas the former concerns preventing misuse of nuclear and other radioactive material by persons or entities other than states. In other words, nuclear security is primarily about combatting criminal acts, nuclear terrorism being chief among them. That is not to say that the line is absolute. Criminal acts can lead to nuclear weapons development by states, such as in the case of A.Q. Khan, who stole centrifuge designs and information on acquiring materials and components for fissile material production from URENCO in the Netherlands and used them in his native Pakistan to establish a nuclear weapons program, in addition to supplying nuclear weapons programs in Iran, North Korea and Libya. According to the respective understandings of the terms, the theft of information would be pertinent to nuclear security, while the development of nuclear weapons by Pakistan concerns nuclear proliferation. Of course, proliferation of nuclear weapons and related materials can also be directed to non-state actors rather than other states, for instance in the case that a state transfers or sells a nuclear weapon to a non-state group ${ }^{11}$ so non-proliferation is an approach that is also applicable to preventing nuclear terrorism. Again, the line is thin and quite gray.

Nuclear security has been placed high on the international agenda in the past number of years, not least of all due to high-level attention it received under the US presidency of Barack Obama. This is not to say that nuclear security is an entirely new phenomenon. Nuclear security is a broad area, defined by a substantial body of rules, norms, principles and guidelines at the international, regional and national levels, developed over several decades. However, this

11 Some have raised this as a concern specifically in respect to North Korea's nuclear weapons program, quoting previous US Secretary of State Robert Gates referring to North Korea as willing to "sell anything they have to anybody who has the cash to buy it." See G. Allison, 'North Korea's Lesson: Nukes for Sale,' The New York Times, 12 February 2013. 
development has been characterized by an ad hoc and fragmented approach resulting in considerable shortcomings with respect to the international legal framework, whether it be certain gaps in the law or inadequate national implementation of international obligations or the lack of mechanisms to provide assurances of compliance with commitments (whether deriving from hard or soft law ${ }^{12}$ instruments).

The relatively recent increased focus on nuclear security in the international discourse ${ }^{13}$ is in great part due to two interrelated issues: first, the acknowledged vulnerability of a significant amount of nuclear ${ }^{14}$ and other radioactive materia ${ }^{15}$ throughout the world, both as part of and outside of military pro-

12 "Soft law" is an oft-debated concept in legal academic discourse. It, however, plays an essential part in the international legal framework for nuclear security and will, therefore, be a central component of the theoretical framework for this study, as discussed in a subsequent chapter.

13 For instance, the Office of Nuclear Security within the International Atomic Energy Agency (IAEA) - as of 2014, it has been raised to the level of Division of Nuclear Security - was only established in 2002.

14 "Nuclear material" is defined in par. 112 of The Structure and Content of Agreements between the Agency and States Required in Connection with the Treaty on the Non-Proliferation of Nuclear Weapons (INFCIRC/153 (Corrected)). This definition refers to any source or any fissionable material as defined in Art. XX of the IAEA Statute. "Source material," according to Art. XX(3) of the Statute, means uranium containing the mixture of isotopes occurring in nature; uranium depleted in the isotope 235; thorium; and any of the foregoing in the form of metal, alloy, chemical compound, or concentrate. "Special fissionable material," as defined in Art. XX(1) of the Statute, means plutonium-239; uranium-233; uranium enriched in the isotopes 235 or 233 (meaning "uranium containing the isotopes 235 or 233 or both in an amount such that the abundance ratio of the sum of these isotopes to the isotope 238 is greater than the ratio of the isotope 235 to the isotope 238 occurring in nature"); and any material containing one or more of the foregoing. A broader definition is included in Nuclear Security Recommendations on Radioactive Material and Associate Facilities, IAEA (Nuclear Security Series No. 14), which defines "radioactive material" as "any material designated in national law, regulation, or by a regulatory body as being subject to regulatory control because of its radioactivity," which includes nuclear material, sealed sources, unsealed radioactive material and radioactive waste.

15 "Other radioactive material" refers to "any radioactive material that is not nuclear material," see Nuclear Security Recommendations on Radioactive Material and Associate Facilities (Nuclear Security Series No. 14). "Radioactive sources" are a separate, common category of material referred to in the legal framework for nuclear security. According to the Code of Conduct for the Safety and Security of Radioactive Sources,

"radioactive source" means radioactive material that is permanently sealed in a capsule or closely bonded, in a solid form and which is not exempt from regulatory control. It also means any radioactive material released if the radioactive source is leaking or broken, but does not mean material encapsulated for disposal, or nuclear material within the nuclear fuel cycles of research and power reactors. 
grams, and, secondly, the demonstrated desire to obtain, and expected willingness on the part of terrorists or terrorist groups to use, such materials. The former concern stems in part from the fall of the Soviet Union and end of the Cold War, which led to unaccounted for and unsecured materials and facilities, as well as from the increased demand for various uses of nuclear energy and the extensive global use of radioactive materials in peaceful activities. With respect to concerns about the threat of nuclear terrorism, one could point to the terrorist attacks on 11 September 2001 as the defining event, in the same way that the Chernobyl accident prompted strengthening the global framework for nuclear safety, and the situation in Iraq in the 1990s led to developments in the verification system for nuclear non-proliferation. ${ }^{16}$

The evolution of the legal framework for nuclear security over time traces several milestones, both related to the establishment and development of the nuclear non-proliferation regime and the post-9/11 actions aimed at combatting the threat of weapons of mass destruction (WMD, i.e. chemical, biological and nuclear weapons) terrorism. Following the entry into force of the Treaty on the Non-Proliferation of Nuclear Weapons (NPT) in 1970, recommendations on physical protection of nuclear material were developed by the International Atomic Energy Agency (IAEA) in $1972^{17}$ and negotiations commenced in 1977 on what would become the main multilateral treaty in the area of nuclear security, the Convention on the Physical Protection of Nuclear Material (CPPNM). Thereafter, the nuclear security regime progressed rapidly following $9 / 11$, including through action by the United Nations (UN) Security Council, namely resolutions 1373 and 1540 and others related thereto; the relatively recent adoption and entry into force of relevant legal instruments such as the 2005 Amendment to the CPPNM and the International Convention for the Suppression of Acts of Nuclear Terrorism (ICSANT); the establishment of nuclear security-related multilateral initiatives, including the Global Initiative to Combat Nuclear Terrorism (GICNT) and the Global Partnership Against the Spread of Weapons and Materials of Mass Destruction (Global Partnership, GP); and the Nuclear Security Summit (NSS) process initiated in 2010. The result of this significant but piecemeal development of approaches to nuclear security, described in more detail in the following chapter, has been a complex

16 This argument was made by Laura Rockwood, former section head for Non-Proliferation and Policy Making at the IAEA's Office of Legal Affairs, in her remarks during a panel discussion focused on 'How the Evolving Domestic, Regional, and IAEA Safeguards Requirements and Practices are Influencing Safeguards Implementation and Culture,' at the 55th Annual Meeting of the Institute of Nuclear Materials Management, 22 July 2014.

17 Subsequently revised in 1975 and published as Information Circular (INFCIRC/225). 
web of legally binding instruments (treaties, Security Council resolutions); guidelines, recommendations and technical documents produced by the IAEA (providing details, inter alia, of legal and regulatory action to implement international obligations in domestic systems); collective law enforcement activities (i.e. through Interpol); regional and international collaborations (often under the auspices of regional or international organizations); and political partnerships establishing shared principles and providing a platform for coordinated projects, all forming part of the overall nuclear security regime.

The ad hoc development of the nuclear security regime has a lot to do with technical complexities and political sensitivities inherent in the area of nuclear security, which impact the prospects for international law-making. Nonetheless, due to the potentially drastic implications for international peace and security should a nuclear terrorist attack take place, meaning that states have a fundamental security interest in other states taking necessary measures to prevent nuclear terrorism, it stands to reason that there is need in the area of nuclear security for legal obligations for which states can be held accountable. Where traditional law-making is not possible, due, for instance, to those same technical complexities and political sensitivities, the international legal framework for nuclear security demonstrates that "soft law" provides a fairly effective form of international cooperation as a complement and supplement to the relevant legally binding instruments. That is not to say that the international legal framework cannot be strengthened. The framework for nuclear security could be enhanced by expanding the scope of the legally binding instruments or adopting new legally binding instruments to fill in gaps, adapting the soft law instruments as necessary to address emerging threats, and developing a system of supervision to help ensure compliance with the rules.

The starting point for an exploration of the international legal framework for nuclear security is placing it in its broader context of international arms control law. The law developed to prevent non-state actors, namely terrorists, from obtaining, producing and/or using nuclear or radiological weapons should be seen as an integral part of international arms control law. Examining nuclear security in this context has to do with a number of specific characteristics of both nuclear security and arms control law as a branch of public international law. One is the centrality of security, meaning that the legal framework for nuclear security, as is the case for international arms control more generally, is aimed at enhancing national, regional and global security. The element of security means that states will be more likely to enter into agreements and make commitments if they feel that doing so will enhance rather than be detrimental to their security, by, for example, giving a strategic military advantage to a potential adversary. For this reason, supervision, or some other form of assurances of compliance are important. Supervision plays a key role in international arms control law, and it is relevant to the legal framework for 
nuclear security, even if it is an element largely lacking in the nuclear security framework right now.

A second characteristic of the legal framework for nuclear security that places it squarely in the context of international arms control law is the focus on control of weapons as well as of the component parts of weapons. There are, of course, some differences between nuclear security instruments and "traditional" arms control law instruments in this sense, which have to do with the slightly different nature of the two, namely the focus the weapons possessed by states versus weapons possessed by non-state actors.

Understanding the international legal framework for nuclear security as part of arms control law helps elucidate the legal framework for nuclear security's characteristics, approaches and rationale, as well as its shortcomings, and serves to conceptualize ways to further strengthen the nuclear security legal framework. This book provides a comprehensive overview of the international law applicable to nuclear security. In so doing, it establishes a framework for better understanding how the international law related to nuclear security is structured and why it is structured in this way; provides a critical analysis of the component instruments that make up the framework, thereby analyzing possible shortcomings of said instruments or the legal framework as a whole; and gives a prescriptive assessment looking at how relevant legal mechanisms, processes and institutional arrangements (including, for instance, review, amendment and/or supervision) can be developed, invoked or employed to facilitate efforts to enhance the effectiveness of the legal framework in light of its aim to prevent nuclear terrorism. Nuclear security is by no means a static topic. New developments, whether in terms of the threat of nuclear terrorism or with respect to political or technical considerations, are occurring frequently. Changing circumstances is a defining feature of the area of nuclear security. Such a book is, therefore, always a product of its time. The main focus, though, is of course on arriving at an interpretation and analysis of the international law of nuclear security that is of general application, and as such any time-sensitive information is used solely to inform the analysis.

The rest of this chapter more fully describes the context for the legal framework for nuclear security, namely as an integral part of international arms control law, and it also introduces the concept of nuclear security governance, which helps explain how the elements of the nuclear security regime fit together. The next chapter traces the development of the international legal framework for nuclear security over time, showing how the framework has developed largely in a fragmented manner, resulting in the limited scope of relevant treaties, the extensive body of non-binding "soft law" instruments, and the limited powers and functions of international organizations in terms of their nuclear security-related roles. The third and fourth chapters examine the body of legally binding instruments applicable to nuclear security at the 
international level, namely multilateral treaties, including the main nuclear security treaties as well as the criminalization provisions of the wider body of applicable counter-terrorism treaties, and UN Security Council resolutions. These chapters thereby demonstrate a key feature of the legal framework for nuclear security, namely the combination of arms control and criminal justice approaches. The fifth chapter considers the relationship between the relevant "hard" and "soft" law, which is a central tenet of the legal framework for nuclear security, demonstrating that normative soft law, which in principle is more easily adaptable and can potentially provide greater technical precision while still serving to shape the behavior of states, offers a form of cooperation when traditional law-making might not be possible or advisable. Chapter 6 analyzes the role of the relevant international organizations that are involved in the international legal framework for nuclear security. International organizations play a crucial role in the field of arms control law generally, namely as a fundamental part of the supervisory process to monitor and control compliance with multilateral arms control treaties, but the role in nuclear security is much more limited even though supervision or oversight of compliance with the relevant instruments could serve to strengthen the legal framework for nuclear security. The final chapter concludes with a discussion of specific concrete means and methods that could help strengthen the international legal framework for nuclear security.

\subsection{FORM AND CHARACTERISTICS OF INTERNATIONAL ARMS CONTROL LAW}

Arms control law is part of the broader rules and norms of public international law relating to international peace and security. As the scope of international law has expanded, the preservation of peace and security, through, inter alia, the principle of the non-use of force, has remained a central concern of the international legal order. ${ }^{18}$ This is spelled out clearly in the first article of the UN Charter, stating that among the purposes of the UN is the maintenance of international peace and security through collective measures to prevent threats to the peace, to suppress breaches of the peace and to settle international disputes by peaceful means. ${ }^{19}$ This is the foundation of the UN system of collective security, which pursues the peaceful settlement of disputes and regulates the resort to the use of force, either in self-defense as a response to an armed

18 Shaw notes that the scope of international law has expanded beyond the primary concern of international peace to encompass various areas of international relations; $\mathrm{M}$. Shaw, International Law, 7th edition, Cambridge: Cambridge University Press (2014), pp. 31-35.

19 UN Charter, Art. 1(1). 
attack $^{20}$ or as part of an enforcement action mandated by the Security Council to restore peace and security, having determined a threat to the peace, breach of the peace or act of aggression. ${ }^{21}$ Peace and security in the Charter's conception concerns more than just a negative peace, meaning the absence of war. It also entails international cooperation to work towards economic and social stability within and among states. ${ }^{22}$ Even peace in the sense of an absence of war and defined by international cooperation is not necessarily synonymous with security.

Arms control law is directly related both to the rules governing the use of force, in that limitation of armaments and certain military capabilities can limit the possibility and effect of resorting to force, as well as to the conduct of armed conflict in restricting the means and methods of warfare through regulation of state arsenals. Arms control law, in eliminating certain types of weapons or establishing a bilateral or multilateral equilibrium/balance in the level of armaments of states, often confirmed through applicable verification mechanisms ${ }^{23}$ and reflecting the fact that absolute security is unattainable, can help to preserve peace and avoid war. A related humanitarian element is that arms control law can restrict or do away with weapons that cause excessive damage or suffering, and it is often informed by that concern. ${ }^{24}$

Therefore, to place international arms control law in the broader spectrum of branches of public international law, it is related to and overlaps with other areas of the law that concern use of force (law of collective security) and the conduct of hostilities (international law of armed conflict). Arms control law is meant to work and be applied in both times of peace and times of war. Arms control law comprises a quite extensive body of instruments that generally concern a common subject matter (regulation of armaments) and aim for

20 UN Charter, Art. 51.

21 UN Charter, Art. 39 in conjunction with Art. 42.

22 See R. Wolfrum, 'Article 55 (a) and (b),' in B. Simma et al. (eds.), The Charter of the United Nations: A Commentary, 2nd edition, Oxford: Oxford University Press (2002), pp. 897-917. Sur refers to this as the preventive approach or "soft security," focusing on "economic and social progress, public health, cultural cooperation, education, universal and effective respect for human rights and all without any form of discrimination"; S. Sur, International Law, Power, Security and Justice: Essays on International Law and Relations, Oxford: Hart Publishing (2010), pp. 256-259. This is as opposed to Sur's conception of "hard security," which involves military action both to discourage military threats and, if necessary, to respond to armed violations of international peace.

23 To give parties assurance that breaches will be detected if they occur so that other states will not be at a military, tactical or strategic disadvantage.

24 See, for instance, the 1997 Convention on the Prohibition of the Use Stockpiling, Production and Transfer of Anti-Personnel Mines and on their Destruction. 
a common objective (eventual general and complete disarmament). ${ }^{25}$ Thus, this body of instruments, which make reference to and build upon one another and which share common features as described below, can be considered to constitute a branch of public international law, falling under the broader context of the law related to international peace and security.

Though there may be no generally accepted definition of arms control, ${ }^{26}$ it is traditionally, or classically, thought of as encompassing regulation of, limitations on or elimination of certain military capabilities between or among (potential) adversaries. It is often described in terms of certain principles and objectives like reducing the likelihood of war, namely nuclear war; limiting the extent of damage should war occur, death and destruction being more catastrophic if nuclear weapons are used; fostering stability and predictability; and reducing expenditures on military forces. ${ }^{27}$ Bull refers to this latter objective as secondary in a hierarchy of objectives, the first being the reduction of the likelihood and potential destructiveness of war, and a third being a moral and social goal of combatting society's militarization. ${ }^{28}$

Arms control $l a w^{29}$ involves the development and codification of rules, norms and standards to achieve the broader arms control structure and

25 G. Den Dekker, The Law of Arms Control: International Supervision and Enforcement, The Hague: Martinus Nijhoff(2001), p. 36. The goal of general and complete disarmament is tempered in the UN system of collective security by allowing at least the minimum level of armaments needed for a state to defend itself and take part in collective military enforcement measures under Art. 42 of the UN Charter.

26 Ibid., p. 22.

27 See T. Schelling and M. Halperin, Strategy and Arms Control, New York: Twentieth Century Fund (1961); H. Bull, 'Arms Control and World Order,' 1976 International Security, no. 1, pp. 3-16; and E. Dahinden, 'The Future of Arms Control Law: Towards a New Regulatory Approach and New Regulatory Techniques,' 2005 Journal of Conflict \& Security Law, no. 2, pp. 263-277.

${ }_{28}$ Bull, 'Arms Control and World Order,' at 4. See also E.P.J. Myjer, 'Hedley Bull: The International Lawyer and the Use of Force,' 1993 Leiden Journal of International Law, no. 1, pp. 171-193.

29 Freeman refers to arms control as a larger concept than arms control law, the legal dimension being "distinct and normative in character but not exhaustive of practice"; J. Freeman, 'Is Arms Control Law in Crisis?', 2004 Journal of Conflict \& Security Law, no. 3, pp. 303-313. Myjer and Den Dekker note that arms control law, at its most fundamental, is about limitation of military power; E.P.J. Myjer and G. Den Dekker, 'Wapenbeheersingsrecht,' in N. Horbach et al. (eds.), Handboek Internationaal Recht, The Hague: TMC Asser Press (2007), p. 594. See also I. Anthony, 'Reflection on Continuity and Change in Arms Control,' 2006 SIPRI Yearbook: Armaments, Disarmament and International Security, Stockholm: Stockholm International Peace Research Institute (2006), p. 596, in which it is argued that in a "modern understanding" legal instruments comprise one among several elements that together make up arms control. 
objectives, legal agreement often being the goal and result of arms control processes. Agreement, or consent, is key as the starting point is the freedom to possess armaments unless a state accepts rules by which its level of armaments is limited. ${ }^{30}$ Agreements to accept such rules can be bilateral, regional or international. Agreements can take a number of different forms, from hard law such as treaties, conventions, decisions of international organizations and protocols; to softer forms of rule-making and norm-setting (soft law) such as recommendations and guidelines, memoranda of understanding and codes of conduct; to political commitments contained in joint statements and declarations, and final documents of international conferences. ${ }^{31}$ Arms control agreements have involved various types and measures of control: disarmament (including reducing or abolishing certain categories of weapons); limitations on the numbers or deployment of armed forces and weaponry; non-proliferation (preventing the spread of weapons, whether to states or to non-state actors); prohibitions on the testing of weapons, namely nuclear weapons; proscriptions of or regulations on the transfer of militarily relevant items, including nuclear material and related technology; constraints or prohibitions on certain weapons during armed conflict (or methods of war); and measures to build confidence (such as through increasing openness and transparency in military matters). ${ }^{32}$ In light of more recent developments, one could add to this list measures to control materials (i.e. nuclear and other radioactive materials) that could be weaponized, with the aim to prevent development, acquisition and/or use by non-state actors.

As mentioned above, arms control law is characterized by the centrality of security considerations. Security as a concept has both an objective and subjective dimension. The objective dimension can be thought of to denote the absence of threats to interests and values, while the subjective side denotes an absence of fear from attacks on such values. ${ }^{33}$ Security is not an either-or proposition, meaning that a state is not either secure or insecure, but rather it has various degrees. International security can be thought of as a function of the relative security of each state in the global order. ${ }^{34}$ The collective security

30 Case Concerning Military and Paramilitary Activities in and Against Nicaragua (Nicaragua v. United States of America), ICJ Reports 1986, par. 269. The Court goes on to say that "this principle is valid for all states without exception."

31 Goldblatt lists a number of these forms: J. Goldblat, Arms Control: The New Guide to Negotiations and Agreements, 2nd edition, London: Sage Publications (2002).

32 See ibid., p. 3.

33 A. Wolfers, 'National Security as an Ambiguous Symbol,' in A. Wolfers (ed.), Discord and Collaboration: Essays on International Politics, Baltimore, MD: Johns Hopkins University Press (1962), pp. 147-165.

34 See Den Dekker, The Law of Arms Control, pp. 27-35. 
system of the UN, for instance, draws on the basic security of states, but entails a compromise on the perception of security around common values and principles (non-use of force, non-intervention), a determination of encroachment upon those values and principles and the taking of collective action to preserve them or restore order. This gives arms control law as an area of international law a special character, as it is part of broader efforts to support international, and by extension national, security. ${ }^{35}$ This means that a state will enter into an arms control agreement if it feels that doing so will strengthen or at least underscore its security, whether that be military in nature (military security), relating to the state's ability to defend itself and to participate in collective security actions, or related to other aspects of security such as economic or energy security (important when it comes to regulating nuclear energy to ensure its use solely for peaceful purposes), among other areas of "interest" security. Efforts aimed at preventing terrorist attacks involving nuclear or other radioactive material, or related facilities, are fundamentally about national and international security.

Among the rights and obligations established by arms control agreements, provisions supporting aspects of interest security of states are frequently included to provide incentives for becoming party to multilateral arms control treaties with the aim of universalization. This is true in particular with regard to treaties related to WMD, which concern inherently "dual-use" material, processes and technologies, meaning those with both peaceful and military applications. States are encouraged to become parties in order to enjoy the full benefits of peaceful uses of these materials and technologies. Article XI of the Chemical Weapons Convention (CWC), for instance, affirms the right of states parties to benefit from peaceful applications of chemicals, requiring that the treaty be implemented in such a way as not to hamper the economic and technological development of states parties. Further, states parties have the right to conduct research with, as well as to develop, produce, acquire, retain, transfer, use and participate in trade in chemicals for purposes not prohibited under the treaty. The CWC also sets out rights and measures to ensure assistance to and protection of states parties against attack or if threatened by attack with chemical weapons. ${ }^{36}$ The NPT contains similar provisions on facilitating the enjoyment of benefits of peaceful applications. Under the NPT, the non-nuclear weapon states (NNWS) give up nuclear weapons ambitions and submit to a system of supervision (the IAEA safeguards system ${ }^{37}$ ) to ensure no

See Myjer and Den Dekker, 'Wapenbeheersingsrecht,' p. 598.

CWC, Art. X.

37 The safeguards system comprises the provision of the IAEA Statute and safeguards agreements modeled on INFCIRC/153 (corrected), otherwise known as a comprehensive safeguards agreement, as well as the Model Additional Protocol 
diversion of peaceful-use nuclear material to nuclear weapons, in exchange for the recognized right to peaceful uses of nuclear energy and a commitment by nuclear weapon states (NWS) to negotiate toward nuclear disarmament. Here, again, the right of states parties to participate in the exchange of equipment, materials, and scientific and technological information for peaceful activities is established, with specific reference to development of peaceful applications of nuclear energy within NNWS and with due consideration for the needs of developing states. ${ }^{38}$ Nuclear security plays an important role in the peaceful use of nuclear energy in line with the right set out in Article IV of the NPT, as evidenced by considerations of nuclear security not only as part of the non-proliferation pillar of the NPT, but also as part of the peaceful uses pillar in the context of NPT review conferences, ${ }^{39}$ though there is a range of views as to whether efforts to strengthen nuclear security are a prerequisite for or hamper cooperation in peaceful nuclear activities. ${ }^{40}$

Disincentives are also employed to convince states to adhere to arms control agreements. For instance, the Nuclear Suppliers Group disallows nuclear trade with states that are not party to the NPT and in full compliance with NPT obligations, ${ }^{41}$ though it must be pointed out that a waiver was accorded to India, which is not a party to the NPT, in 2008. The CWC for its part has a provision

(INFCIRC/540), which extends the power of the IAEA with respect, inter alia, to gathering information and having site access. Many states see the comprehensive safeguards agreement plus the Model Additional Protocol as the safeguards standard for fulfilling Art. III of the NPT. The objective of the safeguards system is to detect and deter the diversion of significant quantities of nuclear material from peaceful nuclear activities to the production of nuclear weapons or of other nuclear explosive devices for purposes unknown. For a good description of the IAEA safeguards system see T. Coppen, The Law of Arms Control and the International Non-Proliferation Regime, Leiden: Brill Nijhoff (2016), pp. 123-152, 255-331; and Den Dekker, The Law of Arms Control.

38 NPT, Art. IV.

39 See, for instance, par. 58 and Actions 57, 60 and 62 of the Final Document of the 2010 Review Conference of the Parties to the Treaty on the Non-Proliferation of Nuclear Weapons, NPT/CONF.2010/50 (Vol. I).

40 That nuclear security requirements could hamper cooperation in peaceful use is an argument often made predominantly by G77 states, who argued in favor of the inclusion of a paragraph in the 2016 nuclear security resolution adopted by the IAEA General Conference (GC(60)/RES/10) to the effect that states should ensure that measures to strengthen nuclear security "do not hamper international cooperation in the field of peaceful nuclear activities, the production, transfer and use of nuclear and other radioactive material, the exchange of nuclear material for peaceful purposes and the promotion of peaceful uses of nuclear energy, and do not undermine the established priorities of the Agency's technical cooperation programme."

${ }^{41}$ See Guidelines for Nuclear Transfers (NSG Part 1 Guidelines), INFCIRC/254/ Rev.13/Part 1 (8 November 2016), par. 6. 
that, following three years after entry into force, transfers of Schedule 2 chemicals under the treaty will only be allowed among states parties to the CWC. ${ }^{42}$

The security dimension of arms control also means in general that a state will only accept restraints on its possession of armaments if it is confident that other states are adhering to their obligations and if breaches of obligations will be detected. In "traditional" arms control agreements, this aspect is meant to assure states that other states - potential adversaries - are not gaining military advantages that could be used to their strategic disadvantage. ${ }^{43}$ Supervision, including but not necessarily limited to verification, is thus part and parcel of arms control law. The supervisory role can be undertaken by the states themselves, as is often the case for bilateral arms control agreements such as New START, ${ }^{44}$ or in the most far-reaching cases by specially created or specially tasked international organizations pursuant to multilateral treaties. The IAEA, the Organization for the Prohibition of Chemical Weapons (OPCW) and, upon the entry into force of the Comprehensive Nuclear-Test-Ban Treaty (CTBT) which bans all nuclear test explosions, the Comprehensive Nuclear-Test-Ban Treaty Organization (CTBTO), are examples of international institutionalized arms control law supervision, for the NPT, CWC and CTBT, respectively.

Myjer has developed a clear and useful model that describes supervision as it pertains to arms control treaties. ${ }^{45}$ The model foresees four main functions of supervision: collection, review, creative and correction. Collection of relevant information (through, inter alia, legally obligated declarations), review of said information and judging the behavior for conformity with the relevant legal rules, and interpreting or clarifying the rules (creative function) together form the process of verification. Verification is meant to produce clear and convincing evidence of a state's compliance or non-compliance with legal obligations in a timely manner. ${ }^{46}$ Techniques for verification can vary but include on-site inspection, containment and surveillance and national

42 CWC, Verification Annex, Part VII, par. 31.

43 See E. Myjer and J. Herbach, 'Violation of Non-proliferation Treaties and Related Verification Treaties,' in D. Joyner and M. Roscini (eds.), Non-proliferation Law as a Special Regime, Cambridge: Cambridge University Press (2012), pp. 119-120.

44 Treaty between the United States of America and the Russian Federation on Measures for the Further Reduction and Limitation of Strategic Offensive Arms.

45 E.P.J. Myjer, 'The Organization for the Prohibition of Chemical Weapons: Moving Closer towards an International Arms Control Organization? A Quantum Leap in the Institutional Law of Arms Control,' in E.P.J. Myjer (ed.), Issues of Arms Control Law and the Chemical Weapons Convention, The Hague: Martinus Nijhoff (2001), pp. 104-107. On supervisory processes, see also Coppen, The Law of Arms Control, pp. 42-58 and Den Dekker, The Law of Arms Control, pp. 115-161.

46 See Principles of Verification, UN Disarmament Commission, endorsed by the General Assembly in resolution 43/81 (1988). 
technical means (NTMs), such as satellite imagery. They can also include other international technical mechanisms, such as the International Monitoring System, which is comprised of monitoring stations throughout the world and laboratories designed to detect and analyze nuclear tests and other nuclear explosions, established for the CTBT under the auspices of the Provisional Technical Secretariat (provisional as the CTBT has not yet entered into force). Correction, then, pertains to remedying breaches of a treaty, for which there can be various models such as: provisions contained within the treaty text and having treaty-specific application, such as for the CWC and CTBT; measures contained in verification-related instruments, as in the case of the safeguards system pursuant to the NPT; or reliance on general rules of international law in case of a breach. Measures that can be invoked to address a situation of non-compliance could include restrictions of rights and privileges under the treaty, such as restricting a party's right to access equipment, materials, science and technology benefits as discussed above, interruptions of economic relations, sanctions, countermeasures or reporting situations of non-compliance to the UN Security Council and/or General Assembly, the choice of measures depending in large part on the severity of the breach. ${ }^{47}$ In these latter cases in which a situation is reported to the organs of the UN, the Security Council and General Assembly can take measures in line with their powers and functions under the UN Charter; arms control treaties do not ascribe them additional powers. As the powers and functions derive from the Charter, the UN organs need not necessarily wait for a report of non-compliance from a treaty body; for instance, if a breach of an arms control treaty is deemed by the Security Council to constitute a breach of international peace and security, it may take enforcement measures foreseen under Chapter VII of the Charter.

Another feature of arms control treaties, directly related to the security of the state, is the inclusion of clauses for withdrawal. A standard formulation refers to the right for a state party to withdraw if extraordinary events have

47 See, for instance, G. Den Dekker, 'Article XII: Measures to Redress a Situation and to Ensure Compliance, Including Sanctions,' in Myjer et al. (eds.), The Chemical Weapons Convention: A Commentary, Oxford: Oxford University Press (2014), pp. 365-385. Under the CWC, cases "of particular gravity" are to be brought to the attention of the UN General Assembly and Security Council. Under the IAEA safeguards system, the Board of Governors is to report any cases of non-compliance with safeguards to the Security Council and General Assembly (IAEA Statute, Art. XII(C)). See also A. Fisher, 'Arms Control and Disarmament in International Law,' 1964 Virginia Law Review, no. 7, pp. 1200-1219, in which the author describes the importance of considering responses to possible violations of arms control law agreements at the time of drafting, as this cannot be dealt with adequately after suspected breach has occurred (at p. 1216). 
jeopardized the supreme interests of the state. ${ }^{48}$ This right of withdrawal is seen as a facet of national sovereignty. The threshold - "extraordinary events" and "supreme interests" - is meant to be high, reflecting the significant security stakes for the withdrawing party as well as the other parties to the treaty should one withdraw. The high threshold also relates to the interest in preserving the principle of pacta sunt servanda by not making withdrawal easy. However, justification is left up to the state itself, which is given substantial discretion in determining the need to withdraw. The procedure for withdrawal can differ per treaty, for instance with respect to the period of time prior to withdrawal taking effect that notice has to be given. ${ }^{49}$ Generally, the notice is given to other states parties, the executive body of a treaty organization if applicable, the depositary in the case of the CWC and CTBT, and the UN Security Council. No process for assessing and determining the validity of a notice of withdrawal is explicitly foreseen in these treaty texts, again having to do with national sovereignty and the consent of the party to be bound, but states parties may raise objections, for instance, or the Security Council could determine that such a withdrawal constitutes a threat to international peace and security and take enforcement measures. ${ }^{50}$

Looking specifically at nuclear security, whereas "traditional" instruments are focused on military capabilities and are thus cooperative but inherently adversarial, nuclear security instruments are in principle cooperative based on shared objectives. This difference could to a certain extent explain some main variations, such as weaker withdrawal clauses and the absence or weakness of supervisory mechanisms under nuclear security instruments.

Another important aspect of arms control law is that developments - technical, scientific and with respect to threats or threat perceptions - will often have an impact on arms control treaty regimes, often requiring a certain evolutive capacity, particularly for treaties and regimes of unlimited duration. The need for evolution is accounted for in certain elements of arms control treaties, namely review and amendment processes. Specific review conference provisions are a common feature of treaty regimes concerning WMD. The

48 See NPT, Art. X; CWC, Art. XVI; BWC, Art. XIII; CTBT, Art. IX. See a more in-depth discussion of withdrawal from arms control law treaties in N. Ronzitti, 'Article XVI: Duration and Withdrawal,' in Myjer et al. (eds.), The Chemical Weapons Convention; and G. Den Dekker and T. Coppen, 'Termination and Suspension of, and Withdrawal from, WMD Arms Control Agreements in Light of the General Law of Treaties,' 2012 Journal of Conflict and Security Law, no. 1, pp. 25-47.

49 The NPT has a period of three months, as do the BWC and the CWC (90 days); the CTBT has a period of six months.

50 This was the case with respect to North Korea in light of its withdrawal in 2003 from the NPT, see S/RES/1718 (2006). 
wording of the review conference provisions is fairly consistent across the WMD-related treaties, the aim being to review the operation of the treaties with a view to ensuring that the purposes of the treaty are realized. The purview of review conferences is not explicitly amendment or modification of the treaty itself, though review could be a catalyst for such processes or new instruments. Instead, the evolutionary impact has to do with their role in clarification, development of common understandings or illustration of subsequent agreement/practice that can have a bearing on treaty interpretation. ${ }^{51}$ Amendment or modification, on the other hand, refers to procedures for altering provisions of the treaty with respect to all parties or to two or more parties as between themselves, respectively. Processes for amendment contained in WMD-related treaties vary in terms of procedural requirements for introduction, adoption and entry into force. ${ }^{52}$ Through an amendment process, the treaty can be modified to take account of changing circumstances, for instance by broadening the treaty's scope such as in the case of the CPPNM.

\subsection{BEYOND "TRADITIONAL" ARMS CONTROL: THE SPREAD OF WEAPONS, MATERIALS AND TECHNOLOGIES TO NON-STATE ACTORS}

As mentioned above, nuclear security is not arms control law in the "traditional" sense. Nuclear security, for one, does not necessarily deal with weapons as such, which, for instance, must be limited or destroyed, but rather more comprehensively covers the "building blocks" of weapons, or in other words the materials, and associated facilities, that may have peaceful uses but could also be weaponized, thereby aimed at securing them from illegal use. ${ }^{53}$ While nuclear security is thus not directed at the use or possession of armaments by states as such, it does concern the prevention of development, acquisition and/ or use of nuclear or radiological weapons, only in this case by non-state actors rather than states, which nonetheless falls within the remit of arms control (law). Arms control should therefore not be considered confined to states and

51 See, for instance, Art. VIII, par. 22 of the CWC. For the CWC, with its supervisory organization, the Organization for the Prohibition of Chemical Weapons (OPCW), the review conference mechanism is embedded in the powers and functions of the OPCW, namely in the role of the plenary body, the Conference of States Parties. Treaties without such supervisory bodies will be reviewed by the states parties, see Art. XII of the BWC.

52 Compare Art. VIII of the NPT, pursuant to which at least certain states (namely nuclear weapon states) must approve the amendment, with Art. XV of the CWC, which differentiates between amendments to the Convention and changes to the Annexes. By contrast, Art. XI of the BTWC is highly simplistic.

53 This is generally referred to as the dual-use dilemma. 
military capabilities, but should also be seen as focused on denying capabilities to non-state actors in order to prevent WMD terrorism.

Broadly speaking, nuclear security could involve protection of both existing armaments and the raw materials - nuclear and other radioactive material and related technologies - that go into producing weapons. However, the efforts aimed at protecting material and technology are not limited to the military sphere, but also extend to civilian applications. In other words, the relevant laws and regulations are aimed at preventing potential "military" capabilities of non-state actors by controlling material and technology that could be used in weapons, as opposed to limiting or reducing existing military capabilities of states. In addition, the instruments that make up the law related to nuclear security are concluded between states but are not focused on setting limits on weaponry and forces (types, quantities), but rather on agreeing to and setting standards of protection to prevent items that can be used to produce weapons from falling into non-state actor hands. In general terms, then, preventing non-state actors from developing or acquiring WMD should be considered as part of the basic objectives of arms control. ${ }^{54}$ To this end, one could expand the "traditional" definition of arms control law to refer to: the part of public international law that deals both with the restraints internationally exercised upon the use of military force (in general) and on the use, development, transfer and/ or the possession of armaments (in particular), including their component parts and related technologies, whether in respect of the level of armaments, their character or deployment and with the applicable supervisory mechanisms. ${ }^{55}$

A particular element of nuclear security, and $\mathrm{CBRN}^{56}$ security more broadly, is that it is aimed primarily at prevention. The objective is to prevent non-state actors (terrorists) from developing or obtaining nuclear or radiolog-

54 The CWC incorporates criminalization in the treaty text as part of the national implementation measures (Art. VII). For the BWC, criminalization, though not obligated explicitly in the treaty text, is often incorporated in national implementing legislation. See, for instance, the Australian Crimes (Biological Weapons) Act (1976); the US Biological Weapons Anti-Terrorism Act (1989); the French Law on the Prohibition of Biological Weapons (1972); and Canada's Biological and Toxin Weapons Convention Implementation Act (2008). The NPT is focused on states and does not pertain to criminalization.

55 This is a modification of the definition put forward by E.P.J. Myjer in 'Supervisory Mechanisms and Dispute Settlement,' in J. Dahlitz (ed.), Avoidance and Settlement of Arms Control Disputes, Vol. 2 Arms Control and Disarmament Law, New York: United Nations (1994), p. 151 (modification emphasized in italics).

${ }_{56}$ CBRN, meaning chemical, biological, radiological and nuclear, is the term of art when referring to security of material, related facilities and technologies because this encompasses peaceful applications that can be used for harmful purposes, as well as military applications. WMD is a more specific term referring to the weapons using these materials. Yet these terms are often used interchangeably. 
ical (or chemical or biological) weapons capabilities. ${ }^{57}$ WMD arms control law more generally is preventive in nature - preventing the spread of weapons (non-proliferation) or preventing the possession or use of WMD through disarmament - because of the particularly destructive nature of these weapons. In principle, it does not matter whether they are employed by states in the course of military action (though such use would likely be more destructive) or by terrorists carrying out an attack. The potential impact would be significant in either case. The need for prevention is why non-proliferation is an important part of the counter-terrorism toolbox, ${ }^{58}$ next to other security measures. In fact, control of materials and facilities is a fundamental aspect of arms control to prevent the spread of weapons to states (e.g. nuclear non-proliferation regime) or to non-state actors (e.g. nuclear security). Security Council Resolution 1540 is an instrument, legally binding on UN member states, that clearly brings together these different strands of measures - non-proliferation and other preventive security measures - needed to address the threat of WMD terrorism. ${ }^{59}$ Resolution 1540 labels, inter alia, the proliferation of WMD and their means of delivery, as well as illicit trafficking in WMD, their means of delivery and related materials, as a threat to international peace and security. It is broadly aimed at combatting the threat of WMD terrorism. Under Resolution 1540, the Security Council requires all member states of the UN to adopt and enforce laws prohibiting non-state actors from developing, acquiring, using and transferring nuclear, biological or chemical weapons. In addition, all states must develop and maintain appropriate and effective measures to account for and secure relevant items, including nuclear material, in production, use and storage as well as appropriate and effective physical protection measures, border controls and export controls. Resolution 1540, as a key instrument in the area of nuclear security but also with non-proliferation aspects, is discussed in more detail in a later chapter.

It should also be pointed out that the more "traditional" arms control instruments, focused, inter alia, on nuclear weapons reductions, nuclear disarmament and non-proliferation, can help further nuclear security aims. Aside from the NPT, a Fissile Material (Cut-off) Treaty (FMCT), for instance, aimed at prohibiting production of fissile material for nuclear weapons or other

57 Other aspects having to do with detection, response and mitigation are covered in criminalization and international cooperation provisions rather than the security of material and facilities provisions.

58 See Myjer and Den Dekker, 'Wapenbeheersingsrecht,' p. 596. See also, using the "toolbox" terminology, R. Matthews, "WMD Arms Control Agreements in the Post-September 11 Security Environment: Part of the "Counter-Terrorism Toolbox", 2007 Melbourne Journal of International Law, no. 2, pp. 292-310.

59 S/RES/1540 (2004). Resolution 1540 was adopted by consensus. 
nuclear explosive devices, that would entail verification and possibly cover existing stocks of fissile material, could enhance nuclear security by reducing the amount of weapons-usable material potentially vulnerable to theft and use by malicious non-state actors. Though for decades there has been a call for this "non-discriminatory, multilateral and internationally and effectively verifiable treaty banning the production of fissile material for nuclear weapons or other nuclear explosive devices, "이 efforts to begin negotiations have stalled. Similarly, the bilateral agreements on reductions of nuclear weapons between the United States and Russia, and related efforts to down-blend, mix and/or dispose of the nuclear material from said warheads, reduces risks and threats associated with those materials.

Though part of arms control law, it should be acknowledged that international instruments aimed at preventing non-state actors (i.e. terrorists) from gaining nuclear, and other WMD, capabilities are in some ways different from arms control agreements pertaining to state military capabilities. One way has to do with assurances of compliance. In the area of nuclear security, just as with "traditional" arms control, states are concerned with other states adhering to obligations and commitments, as failure to take appropriate measures in one state can directly affect the security of another state. However, assurances more generally take the form of confidence-building measures rather than verification mechanisms and supervision. Confidence-building measures, or transparency and confidence-building measures or confidence and security building measures, could be codified in a treaty, or be part of a bilateral or multilateral agreement, or be foreseen in a final act of a conference, or entail voluntary measures taken on a unilateral, bilateral or multilateral basis. There is no precise definition of confidence-building measures, but they are identifiable somewhat tautologically by their primary objective, namely to build confidence: in credibility of and adherence to commitments, in peaceful intentions of activities, by enhancing communication and understanding, etc.

Nuclear security, being technically complex and having to do with various activities, processes and functions often considered nationally sensitive - such as national defense, law enforcement and intelligence gathering - as well as fundamental aspects of state sovereignty (such as energy production), does not necessarily lend itself to supervision in the sense of "traditional" arms control instruments, though many of the relevant facilities and materials are already subject to verification under IAEA safeguards pursuant to the NPT. Still, a number of confidence-building steps are available: from legal obligation to report on laws and regulations giving effect to treaty commitments (under the CPPNM and its 2005 Amendment) to voluntarily sharing information on

\footnotetext{
60 A/RES/48/75 L (1993).
} 
measures applied to protect material and facilities, either publicly, directly with other states or confidentially with an international organization, such as the IAEA, for instance through its Nuclear Security Information Management System (NUSIMS). The closest thing to verification under the nuclear security framework are a number of available advisory services: peer review missions voluntarily requested by a state and carried out under the auspices of the IAEA using groups of designated national experts. International Physical Protection Advisory Service (IPPAS) missions, for example, review a state's physical protection system and assess it in line with international instruments, namely applicable treaties and international guidelines. There is no correction function as the instruments tested against are not necessarily legally binding and the mission team has no supervisory mandate, but the action of undergoing one or more of these missions is in itself a confidence-building measure. In addition, the advisory missions provide recommendations for improvements upon which states are not obligated but can be expected to act.

Customary law, as with international arms control law more generally, does not really play a role in the international legal framework for nuclear security ${ }^{61}$ It does not lend itself to the clarity, predictability and often technical specificity required, and as such no customary law can be said to have developed in the area of nuclear security.

However, when it comes to legal sources in the area of nuclear security, soft law plays an outsized role. The lex lata of nuclear security, with only two primary treaties of restricted scope, is admittedly limited if one considers only the Austinian "law properly so-called" and thereby views the relevant soft law as only a device for the attribution of meaning to the settled legal rules. ${ }^{62} \mathrm{Soft}$ law - in the form of, inter alia, guidelines and codes of conduct - plays an important role in the international legal framework for nuclear security. For nuclear security, the binary view of hard law and soft law as law and non-law, the legal value of soft law being mostly restricted to its potential role leading to hard law, is too restrictive. That hard and soft law cannot simply be reduced to a strict dichotomy of binding and non-binding in this case is clear in even a cursory examination of the nuclear security regime. Some characteristics of nuclear security - technical complexities, need for adaptability to deal with changing circumstances and evolving threats - lend themselves more to softer forms of legalization. The legal framework for nuclear security is not unique in employing soft law instruments. Soft law also, for instance, plays a role in

${ }_{61}$ See Myjer and Den Dekker, 'Wapenbeheersingsrecht,' pp. 598-599; Den Dekker, The Law of Arms Control, pp. 62, 64.

62 See B. Simma and A.L. Paulus in S. Ratner and A.M. Slaughter (eds.), Symposium on Method in International Law, 1999 American Journal of International Law, no. 2, pp. 302-316. 
the areas of environmental law, trade and finance, and human rights. ${ }^{63}$ What can be considered unique with respect to WMD arms control law in particular is that the soft law instruments related to nuclear security do not only (or primarily) provide direct normative support for the binding rules, ${ }^{64}$ but also establish "standalone" norms. To illustrate this point, one can look at the Code of Conduct on the Safety and Security of Radioactive Sources, which is the only instrument (hard or soft law) to directly address radiological security. States specifically chose the legally non-binding Code, having considered the possibility of a treaty on radiological security, as the most appropriate form of instrument on this topic and have noted the effect of the Code in strengthening radiological security. ${ }^{65}$

\subsection{NUCLEAR SECURITY COMPARED TO LEGAL APPROACHES TO OTHER WMD}

A number of the characteristics and elements of nuclear security that places it within the context of international arms control law apply to chemical and biological security as well. CBRN security issues are often approached as a whole. ${ }^{66}$ The legal framework for nuclear security is somewhat different however. The primary difference in legal approaches is that the legal frameworks concerning chemical and biological weapons are both focused on disarmament, based on state obligations to destroy or convert existing weapons stocks and related facilities, while at the same time requiring states parties not to develop, produce, acquire, retain or stockpile the respective weapons. ${ }^{67}$ In other words, the primary legal instruments dealing with chemical (CWC) and biological (Biological Weapons Convention, BWC) weapons entail full bans on entire categories of weapons. Nuclear security does not have that basis.

\footnotetext{
63 See D. Shelton (ed.), Commitment and Compliance, Oxford: Oxford University Press (2000).

64 One can think here of the Nuclear Suppliers Group (NSG), which sets norms and guidelines to harmonize members' export control systems in order to support the non-proliferation regime founded in the NPT. Political agreements between the United States and the USSR in the context of strategic arms limitation talks are another example of this, as they can be related back to the obligation to negotiate towards nuclear disarmament pursuant to the NPT, Art. VI.

${ }_{65}$ See International Conference on the Safety and Security of Radioactive Sources: Maintaining Continuous Control of Sources throughout Their Life Cycle, Findings of the President of the Conference, 27-31 October 2013.

66 See, for instance, the 2017 EU Action Plan to enhance preparedness against chemical, biological, radiological and nuclear security risks (also known as the CBRN Action Plan), COM(2017)610.

${ }_{67}$ See BWC, Art. I and CWC, Art. I.
} 
The legal regime relating to nuclear weapons from which the nuclear security framework derives is founded on the NPT, which legally codifies a situation in which certain states - those that had manufactured and exploded a nuclear weapon or other nuclear explosive device prior to 1 January 1967 - retain their nuclear weapons, albeit with the obligation to negotiate toward nuclear disarmament. The legally justified continued existence of nuclear weapons along with military stocks of nuclear material in weapons, dedicated for use in weapons, declared excess to weapons needs or produced for other military purposes, namely naval propulsion - pursuant to the NPT along with the right to use material, facilities and technologies for peaceful purposes without specific obligations related to security of said materials and facilities, explains why a separate framework for nuclear security has been developed.

Another difference is that the CWC, in particular, deals with the issue of non-state actors. The CWC does this in its article on national implementation, which, inter alia, obligates states to prohibit natural and legal persons on its territory or under its jurisdiction from conducting any activity prohibited to states parties under the Convention, and thereby adopting appropriate penal legislation. ${ }^{68}$ The BWC is less specific, only referring to an obligation for states parties not to transfer to "any recipient whatsoever" any agent or toxin having no peaceful application and any weapon, equipment or means of delivery designed to use such agents and toxins for hostile purposes or in armed conflict. ${ }^{69}$ This is similar to Article I of the NPT, which requires that NWS undertake "not to transfer to any recipient whatsoever nuclear weapons or other nuclear explosive devices or control over such weapons or explosive devices directly, or indirectly." In both cases, under the NPT and BWC the phrase "to any recipient whatsoever" is broad enough to cover transfer to state or non-state actors. The focus of the NPT, though, is primarily state-centric, concerning, inter alia, state-to-state proliferation and diversion of material by a state from peaceful to military uses. ${ }^{70}$ Being focused on the threat of non-state actors, the treaties that make up the legal framework for nuclear security contain a criminal justice element, requiring the criminalization of certain acts. For chemical and biological weapons there is not a similar body of security instruments. Each of the treaties that make up the international legal framework for nuclear security, namely the CPPNM as amended and ICSANT, obligate states parties to incorporate new offenses into their domestic criminal codes, thereby establishing bases for jurisdiction, namely the nationality and

68 CWC, Art. VII, pars. 1(a) and 1(c).

${ }^{69}$ BWC, Art. III, read in conjunction with Art. I.

70 See NPT, Arts. I, II and III. 
territoriality principles. ${ }^{71}$ Such criminalization obligations, which follow the prosecute or extradite formula, are standard for the body of counter-terrorism treaties that has been developed since 1963, starting with the Convention on Offences and Certain Other Acts Committed On Board Aircraft, of which the nuclear security-related treaties are considered part. ${ }^{72}$ Though criminal justice is an important aspect of nuclear security, the rules and norms concerning securing material, technology, equipment and facilities (through, for instance, physical protection) in order to prevent them from falling into the hands of terrorist actors are the central and defining tenet of the legal framework for nuclear security. This is because the main feature of nuclear terrorism that makes it potentially particularly devastating is the use of nuclear or other radioactive material. Obtaining the material is the most difficult part of carrying out an act of nuclear terrorism. Still, it is necessary, in order to fully understand nuclear security, to consider both its arms control features and its criminal justice (counter-terrorism) features. The part of nuclear security that can be categorized as counter-terrorism under international law will be considered later in this book.

\subsection{CONTEXTUALIZING NUCLEAR SECURITY IN THE BROADER NUCLEAR NON-PROLIFERATION REGIME}

Two weaknesses of the NPT regime persist - the lack of universality, leaving four states possessing nuclear weapons outside of the treaty regime, ${ }^{73}$ and the fact that the NPT does not adequately address the threat of nuclear terrorism

71 For instance, ICSANT (Art. 9) requires states parties to establish jurisdiction over offenses committed on the territory of the state, on board a sea vessel or aircraft registered to that state at the time the offense is committed, and by a national of that state (territorial and active nationality jurisdiction). The state may also, if it so chooses, establish jurisdiction over offenses committed, for instance, against a state or government facility of a state abroad.

${ }^{72}$ Besides the CPPNM and ICSANT, there are a number of other treaties that have aspects, primarily criminalization provisions, that place them in the framework for nuclear security. These include the International Convention for the Suppression of Acts of Terrorist Bombings, Protocol to the Convention for the Suppression of Unlawful Acts Against the Safety of Maritime Navigation, 2005 Protocol to the 1988 Protocol for the Suppression of Unlawful Acts Against the Safety of Fixed Platforms Located on the Continental Shelf, and the Convention on the Suppression of Unlawful Acts Relating to International Civil Aviation (not yet in force).

73 India, Pakistan and Israel never became party to the NPT and all have developed nuclear weapons. North Korea withdrew from the NPT in 2003, invoking the withdrawal clause in Art. X of the treaty, and has also developed nuclear weapons. 
perpetrated by non-state actors. This latter aspect explains the original rationale for the separate legal framework for nuclear security. ${ }^{74}$

The consensus communique adopted at the first NSS in Washington in 2010 declared nuclear security to be a shared objective alongside the goals of non-proliferation, nuclear disarmament and peaceful uses of nuclear energy, thereby placing nuclear security on the level of the three pillars of the NPT. ${ }^{75}$ Instead of being a "fourth pillar" of the nuclear non-proliferation regime, however, the structure that has been developed for nuclear security - based on the separate body of rules, norms, principles and organization - plays a fundamental role in supporting the elements of the non-proliferation regime.

That nuclear security has a cross-cutting function has long been recognized. The focus on preventing and detecting theft of nuclear material, detecting and responding to illicit trafficking, physically protecting nuclear material and developing nuclear forensics capabilities contributes to realizing broader non-proliferation objectives. ${ }^{76}$ For instance, state systems of accounting and control (SSAC) of nuclear material are of importance equally to non-proliferation and security goals, both to prevent diversion from peaceful to military purposes and to prevent theft or sabotage. Similarly, cooperation to employ nuclear energy for peaceful purposes through transfer of nuclear materials and related technologies requires that those materials and technologies be secured. In other words, a strong nuclear security framework will be instrumental in preventing and detecting diversion of nuclear material, equipment and technology at the state level, thereby supporting the safeguards system, as well as to individuals and groups,${ }^{77}$ while allowing for peaceful cooperation to harness the benefits of nuclear energy.

Nuclear security has increasingly been incorporated into the broader nuclear discussion alongside the three pillars of the NPT. The UN Security Council Summit that resulted in adoption of Resolution 1887, hailed as the Council's first comprehensive action on nuclear issues since the mid-1990s, ${ }^{78}$ included nuclear security-related actions in addition to discussing proliferation, disarmament and peaceful use. Resolution 1887 not only encourages universal

74 See R. Johnson, 'Rethinking the NPT's Role in Security: 2010 and Beyond,' 1993 International Affairs, no. 2; and J. Garvey, 'A New Architecture for the Non-Proliferation of Nuclear Weapons,' 2007 Journal of Conflict and Security Law, no. 3.

75 Communiqué of the Washington Nuclear Security Summit, 13 April 2010.

76 IAEA, Nuclear Security - Measures to Protect Against Nuclear Terrorism, Report by the Director General, GOV/2006/46-GC(50)/13, 16 August 2006.

772015 NPT Review Conference working paper submitted by the Vienna Group of Ten, NPT/CONF.2015/PC.II/WP.9, 6 March 2013.

78 Press release, "Historic Summit of Security Council Pledges Support for Progress on Stalled Efforts to End Nuclear Weapons Proliferation,” 24 September 2009. 
adherence to the 2005 Amendment to the CPPNM and to ICSANT, but it also calls on all states to share best practices in the interest of improving nuclear security practices, to raise standards of nuclear security in order to reduce the risk of nuclear terrorism, as well as to improve national capabilities to detect, deter and disrupt illicit trafficking in nuclear materials. ${ }^{79}$ Furthermore, at the 2010 NPT Review Conference, the Conference of States Parties reiterated the importance of effective physical protection of all nuclear material and the need for stronger international cooperation on physical protection. ${ }^{80}$ In the list of recommendations for follow-on actions, the Conference listed several actions related to nuclear security in the context of both non-proliferation and peaceful uses of nuclear energy. Such actions included encouraging states to maintain the highest possible security standards for nuclear materials and facilities; to apply IAEA recommendations on physical protection of nuclear material and related facilities; to ratify the 2005 Amendment to the CPPNM and become party to ICSANT; to implement the Code of Conduct on the Safety and Security of Radioactive Sources; and to improve efforts aimed at combatting illicit trafficking. Therefore, while nuclear security and its related international legal framework is distinct, it is clearly part of the broader context of arms control law applicable to nuclear weapons and peaceful uses of nuclear energy.

It is estimated that around 80 percent of weapons-usable nuclear material, meaning high enriched uranium (HEU) and plutonium, is in military programs located in the nine states with nuclear weapons. Legally binding physical protection measures, however, do not currently cover military applications of nuclear material. On the contrary, as the primary legal instrument in the area of nuclear security, the CPPNM as amended is solely concerned with materials used for peaceful purposes involved in nuclear energy, research reactors, and medical and industrial capacities, among other uses, and nuclear facilities. The security of military-use materials and related facilities ostensibly falls under the umbrella of nuclear security writ large, but when it comes to the legal framework, the primary focus on peaceful-use material and facilities remains a glaring gap.

\subsection{NUCLEAR SECURITY GOVERNANCE}

One of the primary traits of nuclear security is that it is dynamic, subject to relatively frequent technical, scientific, political, social and economic changes

S/RES/1887 (2009), pars. 21, 24 and 26.

2010 Review Conference of the Parties to the Treaty on the Non-Proliferation of Nuclear Weapons, Final Document, Volume I, NPT/CONF.2010/50 (Vol. I), 18 June 2010. 
that necessarily shape how the regime has developed, the prospects for further strengthening the regime and how states approach this area. One can think of nuclear security, with the broad scope of its definition, as an "issue area." This term suggests a somewhat holistic approach to a subject that involves looking at the range of interlinking elements as a whole - objectives, tools, relevant actors - instead of trying to isolate individual pieces. In other words, rather than a problem to be solved, nuclear security is defined by a comprehensive set of related but distinct goals and is by nature evolving, not least of all in terms of the threat and risks involved. At the same time, the recognized need for some set of international standards is tempered by domestic sensitivities, having to do with the impact on national defense and intelligence sectors, and energy production - often considered fundamental aspects of national sovereignty - which affects the extent to which states are willing to enter into binding obligations. These challenges are reflected in the mixture of treaties, guidelines, codes of conduct, initiatives and political partnerships that characterize approaches to nuclear security. Though it may be tempting to peel apart the components of the regime, which often differ in terms of scope and participation while sometimes overlapping with one another, and assess them on their own merits, such an approach is not necessarily conducive to making sense of how the regime works and would only hinder attempts to determine means and methods for strengthening international nuclear security.

For that reason, it makes sense to think of nuclear security from the perspective of governance. Governance denotes the combined impact of rules and expectations of conduct (substance), on the one hand, and institutional arrangements and process (organization), on the other, which gives shape to and guides the behavior of relevant actors in a given issue area. The interplay of these two elements of a governance structure provides for sufficient evolutive capacity to cope, inter alia, with changes in the threat environment, as well as with the advancement and spread of technologies.

Governance as a model denotes a multifaceted approach - in terms of tools and stakeholders, whether they be states, international organizations, corporations, civil society or individuals - to an issue or topic that favors flexibility in order to account for changing circumstances and evolving needs and interests. International law is an important tool of governance, providing, where necessary, a strong level of obligation and accountability, but so are softer forms of legalization, such as recommendations, guidelines and codes of conduct. These latter tools are, in principle, more easily adaptable and can potentially provide greater precision, but can still serve to shape behavior of those involved, primarily states in the case of nuclear security. Governance can benefit from, or be hampered by, the relationship between the "hard law" and "soft law" instruments, combining obligation and accountability with adaptability and precision. It is not that, for instance, law alone (a treaty) would 
necessarily be insufficient, but it may be preferable in some circumstances, taking into account, for instance, political considerations, to adopt soft law instruments. International law-making, including amending existing agreements, may, for example, be too arduous and time-consuming when addressing particular, perhaps urgent, changing circumstances.

International law contributes both substance and organization to nuclear security governance. The rules are laid down in normative instruments, both legally binding and non-binding, that shape the conduct of states. These instruments - the CPPNM as amended, ICSANT, the Code of Conduct on radioactive sources, the IAEA nuclear security guidance documents - address, inter alia, the establishment and maintenance of systems for protecting nuclear and other radioactive material and facilities, and the criminalization of offenses related to misuse of such material and facilities, and function as a platform for international cooperation. Organization is integrally linked to rules in a variety of ways. It entails the process by which normative instruments are developed, for instance the role of the IAEA in developing and facilitating the adoption of the nuclear security recommendations. It also encompasses institutional arrangements established under treaty frameworks, such as the review conference mechanism for the CPPNM as amended, which can in turn serve to strengthen implementation and further development of specific instruments of the legal framework. Organization refers also to international organizations, the most important of which for the area of nuclear security is the IAEA, which has taken a central role in facilitating the development of member states' domestic nuclear security regimes (through, for instance, assistance upon request in assessing needs based on international instruments) and serving as a convener of processes by which states can interact and discuss issues related to nuclear security. The IAEA also plays a coordinating role among multilateral organizations and initiatives active in the area of nuclear security. The international legal framework provides the basis for nuclear security governance.

The term governance, mostly discussed in the context of international relations, has been used broadly and so many different facets have been projected onto it that there is a risk that it will cease being useful as an analytical tool. Governance has been variously, and non-exhaustively, described as a system of rules backed by shared goals, whether or not backed by law and not necessarily dependent on coercive enforcement; ${ }^{81}$ as a perspective to be used as an

81 J. Rosenau, 'Governance, Order and Change in World Politics,' in J. Rosenau and E. Czempiel (eds.), Governance without Government: Order and Change in World Politics, Cambridge: Cambridge University Press (1992), pp. 3-5. 
organizing framework; ${ }^{82}$ as a set of mechanisms together with the relevant law that applies to those mechanisms $;^{83}$ as a form of policy-making in response to the internationalization of certain problems, ${ }^{84}$ or, even more generally, as the "sum of the many ways individuals and institutions, public and private, manage their common affairs." ${ }^{85}$ In addition, governance is invoked in relation to various levels - from global governance to domestic governance - and in various settings - corporate governance, good governance and so forth.

While governance seems to be a malleable concept, there are a number of distinguishable features that serve as a common thread and illustrate why governance provides a good framework for understanding nuclear security at the international level. First among these is having the basis of common aims, sometimes also called shared goals or "ends," upon which decision-making is based. In the case of nuclear security, common aims include preventing, detecting and responding to unlawful activities involving nuclear or other radioactive material or related facilities. Beyond common aims, there is secondly a level of interdependency when it comes to nuclear security. The acknowledgment that terrorists could seek, and have sought, to exploit vulnerabilities in the security of nuclear or other radioactive material in one state to cause destruction on a massive scale in another, the demonstrated existence of illicit trafficking networks, as well as the porousness of national borders both physically and in cyberspace, have cultivated "mushrooming interdependencies" among states. This can otherwise be portrayed as the predominance of difficult global issues, such as the threat of nuclear terrorism, that require a coordinated international response. Third, then, is the need for cooperation, which realizes the coordinated response. This brings to mind Friedmann's famous exposition of the international law of cooperation, which accounted for growing interdependence and recognized the need not only for making commitments, but also for institutionalization (namely through establishment of international organizations) to fulfill the common interests and provide for the common

82 G. Stoker, 'Governance as Theory: Five Propositions,' 1998 International Social Science Journal, no. 155, pp. 17-28.

83 See, for example, A. von Bogdandy et al., 'Developing the Publicness of International Law: Towards a Legal Framework for Global Governance Activities,' 2008 German Law Journal, no. 11, pp. 1390-1395.

84 W. Werner, 'State Sovereignty and International Legal Discourse,' in I. Dekker and W. Werner (eds.), Governance and International Legal Theory, Leiden: Martinus Nijhoff (2004), p. 128. Werner questions whether modes of policy-making such as governance are a threat to national sovereignty.

85 See Our Global Neighborhood, Report of the Commission on Global Governance (1995), available at http://www.gdrc.org/u-gov/global-neighbourhood/ (last accessed on 15 June 2019). 
welfare of states. ${ }^{86}$ It is, however, important to understand that cooperation in a certain issue area at the international level is conducted not only on an inter-state basis, but also, for instance, through so-called transgovernmental networks of specialized governmental agencies interacting directly with one another, as well as through collaborations with and among non-governmental organizations and interaction at the level of industry.

This leads to perhaps the most important feature of governance: It comprises both formal and informal tools employed to structure cooperation. Formal tools in the sense used here include the legally binding rules, whether in treaties or in other legal instruments such as UN Security Council resolutions, as well as the mechanisms for cooperation and iterative interaction contained in relevant treaties, such as review conferences and reporting. International organizations - those "established by a treaty or other instrument governed by international law and possessing [their] own international legal personality" 87 - are formal tools but are not themselves law, and they may lack legislative power to adopt binding rules applicable to the conduct of their member states, though even then resolutions and decisions of an international organization can have normative effect. On the informal side of the spectrum, the tools include forms of soft law, such as codes (of conduct) and guidelines, memoranda of understanding, and political/diplomatic processes and political partnerships. The formality and informality of the tools, as will be made clearer later in the book, should not be conflated with a judgment on the tools' legal value or effect. The choice of tool employed in a particular situation will depend on several variables, inter alia, motivations of the actors, political calculations, perceived interests, intended and expected consequences, and time considerations. Regardless of the tool ultimately chosen under specific circumstances, the intention is to contribute to the achievement of desired outcomes.

86 W. Friedmann, The Changing Structure of International Law, New York: Columbia University Press (1964).

87 International Law Commission, Draft articles on the responsibility of international organizations, 2011, Art. 2. 